\title{
Troels Fink, Aabenraa, 1912-1999
}

Hvis Troels Fink havde skrevet sine erindringer, havde de ifølge hans eget udsagn fået titlen »Fra Klinkbjerg til Vægterpladsen«. Hermed var markeret to milepæle i Finks liv - barndomshjemmet på Klinkbjerg og det store hus på Vægterpladsen 1, hvor han tilbragte sit mangeårige otium. I luftlinje er det kun $500 \mathrm{~m}$, der skiller de to adresser i Aabenraa. Det er symbolsk for hans stærke tilknytning til byen og landsdelen. Men med yderpunkter i Kobenhavn, Århus og Flensborg kom han til at spænde vidt - såvel som forsker, diplomat og igangsætter.

Troels Marstrand Trier Fink blev født den 18. april 1912 i Aabenraa. Hans far, der blev en kendt sønderjysk arkitekt, var af gammel nordslesvigsk bondeæt og var på modrenes side i familie med H.P.Hanssen. Moderen var en datter af højskoleforstander Ernst Trier i Vallekilde. Med dette afsæt - og født på Dybbøldag - var Troels Fink prædestineret til et virke i den nationale og den sønderjyske histories tieneste.

Som lille fik han selv et første indtryk af nationalitetskampen, da han lige som andre børn fra dansksindede hjem var tvunget til at ga $i$ tysk skole. Det ændrede sig med genforeningen i 1920, der - også i skolemæssig henseende blev oplevet som en stor lettelse af den unge Fink.

I 1930 blev han student fra Aabenraa Statsskole. Herpå drog han til Kobenhavns Universitet, hvor han i 1936 blev cand.mag. med historie som hovedfag og tysk som bifag. I studieårene blev han medlem af en kreds af unge histori-

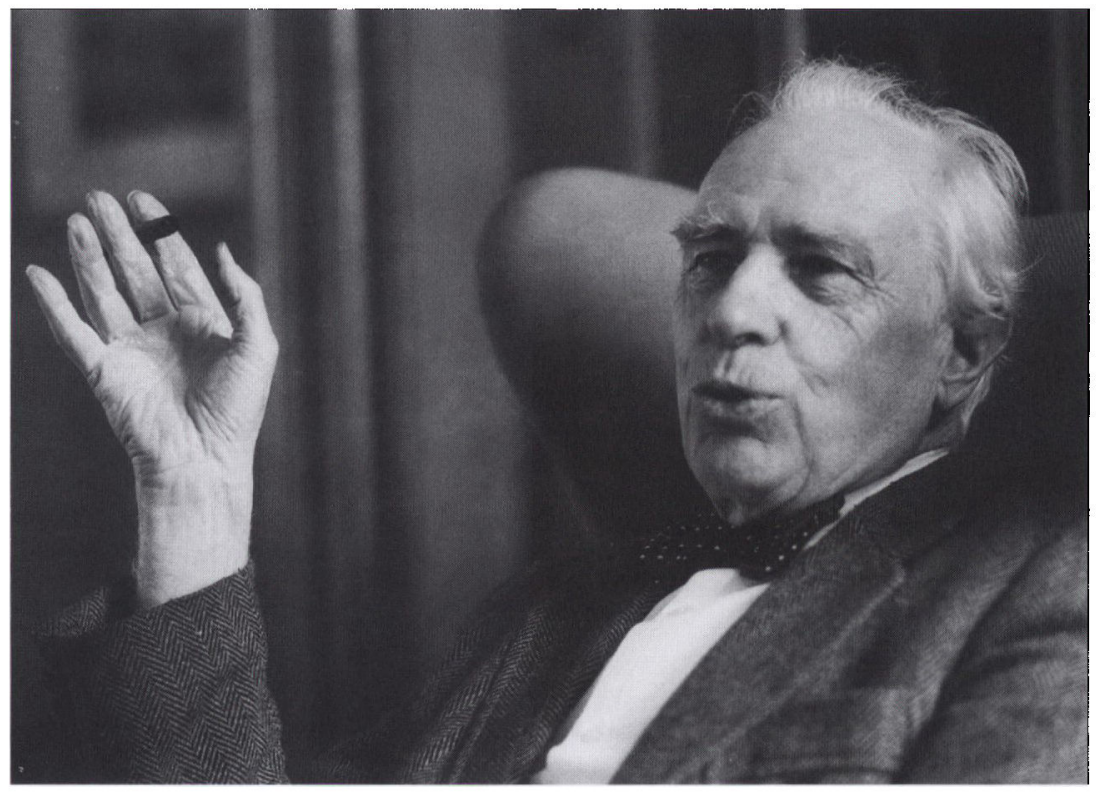

Troels Fink - her som den inspirerende fortæller og samtalepartner. Foto: Lis Sylvest. Institut for sønderiysk Lokalhistorie. 
kere, der - til dels i opposition mod undervisningen og datidens "professorvælde« - oprettede den såkaldte Historikergruppe.

Efter endt eksamen kom Fink tilbage til Sønderjylland. Han blev her sekretær ved den nyoprettede sønderjyske politiadjudantur, som bl.a. skulle overvåge det tyske mindretals aktiviteter. Det gav ham et indgående kendskab til den aktuelle politiske og nationale udvikling i grænselandet - et kendskab der blev udbygget og anvendt på anden vis, da han 1940-1942 som sekretær for De sønderjyske danske Samfund organiserede et omfattende nationalt beredskab i hele Sonderjylland. Det var en udløber af denne virksomhed, da hans hus i Århus blev sprængt i luften i april 1945. Mirakuløst slap Fink og den øvrige familie herfra med livet $i$ behold.

Flytningen til Århus var en følge af den videnskabelige karriere, som Fink havde indledt i 1941 med disputatsen om "Udskiftningen i Sønderjylland indtil 1770«. Den gav i 1942 mulighed for en ansættelse som lektor ved det unge universitet i Århus. I 1946 blev lektoratet omdannet til et docentur i historie med særligt henblik på Sønderjyllands historie og i 1950 gjort til et professorat med samme forpligtigelse.

Tiden i Århus blev meget aktive år. Undervisningen var præget af Finks store viden og giorde indtryk på de studerende. Når talen senere faldt herpå, mindedes de tydeligt Finks evne til at eksercere dem igennem utallige årstal, hertugnavne og begivenheder $\mathrm{i}$ det sønderjyske. Hertil kom en omfattende videnskabelig produktion og anden formidling $\mathrm{i}$ form af foredrag m.v. Det var to sider af Finks virke, der ofte gik hånd $\mathrm{i}$ hånd. Eksempler herpå var "Rids af Sønderjyllands Historie" (1943), "Vejledning i Studiet af Sønderjyllands Historie« (1944, sammen med Johan Hvidtfeldt), "Sønderjylland siden genforeningen " (1955) og "Fem foredrag om dansk udenrigspolitik efter 1864" (1958). Hertil kom to centrale værker: "Spillet om dansk neutralitet 1905-09" og »Ustabil balance. Dansk udenrigs- og forsvarspolitik 1894-1905«, der udkom i henholdsvis 1959 og 1961.

Ved siden af denne virksomhed blev Fink en stor igangsætter på andre områder. I 1946 blev han medlem af den komité, der forberedte oprettelsen af et erhvervsarkiv i Århus; siden var han også i mange år formand for Erhvervsarkivets bestyrelse. I 1949 blev han dekan for det humanistiske fakultet og samme år leder af journalistkursus ved Århus Universitet. I sidstnæunte egenskab blev han en fornyer af journalistuddannelsen. I 1954 spillede Fink en vigtig rolle ved universitetets modtagelse af Sandbjerg Gods som gave fra fru Ellen Dahl, og han blev da også Sandbjergs første administrator. Hertil kom flere andre hverv og tillidsposter.

Stor betydning fik Finks virke 1946-1959 som udenrigsministeriets konsulent i slesvigske spørgsmål. Det var en tid, hvor bølgerne gik højt i Sydslesvig - bl.a. som følge af de slesvig-holstenske myndigheders nålestikspolitik mod det danske mindretal. Som arkitekt bag København-Bonn erklæringerne fra 1955 om mindretallenes rettigheder, var han med til at lægge grunden til den fredelige udvikling, som siden kom til at præge grænselandet. Det var derfor naturligt, at der blev kaldt på professoren, da posten som dansk konsul i Flensborg skulle besættes i 1959. Det skete med personlig titel og rang som generalkonsul. Han var da 47 år gammel. 
I Flensborg kom Fink til at bo og arbejde i 16 år. Med domicil i Nordergraben 19 havde han god udsigt ikke kun over byen men hele grænselandet. Det var en brydningstid, hvor forholdet mellem dansk og tysk bevægede sig fra front til bro. Som den danske stats repræsentant indtog han ikke kun iagttagerens rolle, men var med til at fremme den fredelige udvikling og blev i kraft af sit personlige engagement en stor støtte for det danske mindretal.

Det var et udslag heraf, da der på Finks initiativ i 1963 blev oprettet et historisk institut i Flensborg med det lange navn Studieafdelingen ved Dansk Centralbibliotek for Sydslesvig. Det var en klog disposition. Studieafdelingen har siden udviklet sig til at blive det danske mindretals kollektive hukommelse såvel i kraft af mange udgivelser (afhandlinger, erindringer m.m.) om sydslesvigske emner, som med det meget værdifulde arkiv, der er blevet knyttet hertil.

I 1955 var Fink blevet medlem af styrelsen for Historisk Samfund for Sønderjylland. 1966-1971 var han foreningens formand og blev ved sin afgang æresmedlem. I hundredåret for krigen 1864 udgav han »Otte foredrag om Danmarks krise 1863-64«. Sammen med en tidligere publikation blev den oversat til tysk og i 1968 udgivet med den rammende titel "Deutschland als Problem Dänemarks «. Hertil kom i Flensborg-årene utallige historiske foredrag, medvirken som opponent ved historiske disputatser og meget mere. Det var derfor velfortjent, da han i 1971 modtog byen Kiels kulturpris; samme år fik han også H.V. Clausens og Johan Ottosens legat til danskhedens fremme i Senderjylland.

I 1975 trak Fink sig tilbage som generalkonsul og flyttede til barndomsbyen Aabenraa - men han gik ikke på pension. Karakteristisk for hans virketrang kastede han sig over en ny opgave. Det var således en gammel drem om et sønderjysk institut, der gik i opfyldelse for ham, da Institut for grænseregionsforskning blev oprettet i 1976 i Aabenraa. Med god hjælp af amtsborgmester Erik Jessen var det lykkedes ham at overbevise ikke kun amtsrådet men også staten om det fornuftige $i$ at støtte dette initiativ. Han blev selv instituttets første direktør og udgav her det store tre binds værk "Da Sønderjylland blev delt 1918-1920«. Det er uden tvivl hovedværket i Finks produktion, og er den mest grundige skildring af dette emne.

I 1979 gik Fink af som direktør. Det blev et langt og aktivt otium, der kom til at strække sig over 20 år. Forskningen havde fortsat høj prioritet. I 1986 udkom to binds værket om »Estruptidens politiske historie«, i 1989 »Landsbyfællesskabet i Rinkenæs" og i 1994 - sammen med P. Kr. Iversen - "De Hansborgske Domme 1545-1578«. Trods svær sygdom lykkedes det ham at færdiggøre det imponerende to binds værk med titlen »Båndene bandt. Forbindelsen over Kongeåen 1864-1914“, der udkom en uge efter hans død. Hertil kom flere artikler og indlæg. I alle årene var han fortsat efterspurgt som taler og foredragsholder, lige som mange søgte råd og vejledning hos ham om emner med relation til grænselandets historie. Det var derfor velfortjent, da han i 1986 fik tildelt Rosenkjær-prisen.

I de samme år var Fink med til at sikre, at de såkaldte "Historiske Samlinger", der rummede en meget betydelig billed- og båndsamling på landsarkivet i Aabenraa, blev omdannet til en selvejende institution med amtskommunal støtte. Navnet blev »Institut for Senderjysk Lokalhistorie«. 
Fysisk holdt han sig i form som skovarbejder i egen plantage. Den var et fristed, der gav styrke til sjæl og legeme, men som også blev vist gæstfrit frem. Det var udslag heraf, at Fink i flere år var leverandør af juletræer til venner og bekendte. En del af pensionistårene levede han alene $i$ det store hus på Vægterpladsen, men i 1993 giftede han sig igen. Det blev meget lykkelige år. Da han blev syg i 1998 var det den kærlige pleje og støtte, som han fik af sin hustru Birte, der holdt humøret oppe. Det var i kraft heraf - og af en jernvilje, at han efter et langt sygehusophold kunne genoptage sine daglige sysler i boligen på Vægterpladsen. Her døde han den 26. oktober 1999.

Med rejsen fra Klinkbjerg til Vægterpladsen var cirklen sluttet i en stor sønderjydes liv. På det nationale område var han præget af kampen mod nazismen og hjemmetyske grænseflytningsplaner, men efter 1945 også af erkendelsen af behovet for forsoning med naboen mod syd. Slægtskabet med H.P. Hanssen - og beundringen for hans indsats - fik $i$ den henseende en afgørende betydning for Fink, med respekt for den nationale selvbestemmelsesret og en liberal mindretalspolitik i højsædet.

På det faglige område var han en meget stor kender af Senderjyllands historie. Eftertiden vil her nyde godt af de mange værker, som flød fra hans pen. Men det var også i kraft af denne indsigt og hans store personkendskab, at han $i$ en brydningstid kom til at spille en vigtig rolle som diplomat i grænselandet. Blandt de mange andre ting, som Fink vil blive husket for, er hans virke som igangsætter, hans evne til at tryllebinde tilhørerne, hans humor og ikke mindst hans meningers mod.

En ledetråd livet igennem forblev en dyb forbundethed med den sønderjyske hjemstavn. I den henseende er titlen på Troels Finks sidste værk - „Båndene bandt« - også kendetegnende for hans eget virke.

Henrik Becker-Christensen 